\title{
Patrons against Clients: Electoral Uncertainty and Bureaucratic Tenure in Politicized States
}

\author{
Forthcoming in Regulation \& Governance
}

\section{Author details:}

Dr. Christian Schuster

Assistant Professor in Public Management

School of Public Policy

University College London

29/30 Tavistock Square, London WC1H 9QU, United Kingdom

Email: c.schuster@ucl.ac.uk

\section{Acknowledgements:}

Earlier versions of this work have benefited from generous advice from Martin Lodge, Merilee Grindle, Ed Page and Francisco Panizza as well as participants at the 2015 Aarhus University Workshop on State Bureaucracy and Democratic Development and the 2016 Research Seminar Series of the School of Public Policy at the University College London. The author would like to thank the Latin American Social Science Faculty (FLACSO) in the Dominican Republic for hosting the paper's field research. 


\title{
Patrons against Clients: Electoral Uncertainty and Bureaucratic Tenure in Politicized States
}

\begin{abstract}
Why would incumbents undertake institutional reforms which constrain their discretion over state resources? Many studies point to electoral competition in response. Risking exit from office, incumbents are argued to reform to insure themselves against potentially hostile successors. This paper challenges this line of reasoning, arguing it confounds two potential implications of electoral competition - potential and certain electoral losses which yield contrary reform incentives. Certain exits from office may well incentivize reforms as insurance. Where elections are contested, however, incumbents face incentives to resist reforms that constrain discretion over state resources that provide incumbents with electoral advantage. This argument is developed and assessed with an institutional reform the literature has neglected so far: job stability protections (tenure) in politicized bureaucracies. A case analysis of the Dominican Republic and suggestive cross-country data confirm theoretical predictions: electoral uncertainty dis-incentivizes tenure reform. Electoral competition may thus be a double-edged sword for institutional reform.
\end{abstract}

\section{Key Words}

Civil Service Reform; Electoral Competition; Institutional Reform; Patronage; Tenure 


\section{Introduction}

Why would governments undertake institutional reforms which constrain their discretion over state resources? A broad literature has looked to political competition to account for this conundrum. Incumbents facing uncertainty over future political control are argued to seek institutional reform to constrain - and insure themselves against - potentially hostile successors. Scholars have thus linked political competition with the adoption of freedom of information laws (Berliner, 2014; Berliner \& Erlich, 2015); independent judiciaries (Ginsburg, 2003); anti-corruption laws (Grzymała-Busse, 2006); fiscal transparency (Alt, Lassen, \& Rose, 2006); campaign finance regulations (Grzymala-Busse, 2003); and civil service reform (Horn, 1995; Ruhil \& Camões, 2003; Ting, Snyder, Hirano, \& Folke, 2013). Other studies, however, find the opposite effect. They link political competition to lower state capacity (Besley \& Persson, 2010), and a lower likelihood of institutional reforms (Lapuente \& Nistotskaya, 2009; Meyer-Sahling, 2006).

This paper argues that such inconsistent findings may be expected: political competition may incentivize or dis-incentivize institutional reforms. Where political competition leads to incumbent turnover - and thus certain exits from office - incumbents may well pursue reform as an insurance mechanism. Where it merely leads to electoral uncertainty for incumbents - and thus a potential exit from office -, however, political competition induces a diametrically opposed incentive: to resist reform. Reform would deprive incumbents of access to state resources which can be used for electoral advantage. It thus jeopardizes the electoral mobilization capacity of incumbents when they need it most: under contested elections. Two distinct potential empirical implications of political competition - electoral uncertainty and certain incumbent turnover - thus have antithetical effects on institutional reforms. This suggests political competition is a two-edged sword for institutional reforms. 
This argument is developed and assessed in the context of an institutional reform which the literature has neglected so far: the introduction of job stability protections (tenure) for public servants in patronage states. Patronage states can be conceptualized as those states in which political criteria trump merit criteria in the recruitment of most public servants - or, in other words, those in which patronage governs most bureaucratic appointments (Grindle, 2012). Such states account for almost two thirds of developing countries according to a global expert survey (Dahlberg, Dahlström, Sundin, \& Teorell, 2013). Good governance advocates frequently seek their reform. The World Bank (2008), for instance, lent US\$422m annually for civil service reforms in 2000-2006. The motivation is simple: patronage is linked to clientelism and corruption. It enables incumbents to recruit, on a large scale, loyal party workers to support electoral campaigns and loyal bureaucrats to strip state assets and skew public services and decisions in favour of party supporters (O'Dwyer, 2006). As such, patronage frequently engenders incumbency advantages - and its reform overwhelmingly fails due to political resistance (World Bank, 2008).

Under what conditions patronage reform does become incentivecompatible, however, remains "most poorly understood" (Fukuyama, 2014, p. 26). This holds all the more for reforms to introduce tenure in states with politicized recruitment. While a range studies assesses the determinants of civil service reforms, these typically explain meritocratic recruitment (merit) rather than tenure reforms - or assume both coincide (Dahlström, Lapuente, \& Teorell, 2012; Silberman, 1993). Yet, such coincidences are rare. Merit and tenure are poorly correlated in the Quality of Government Expert Survey data for 128 countries (r=0.12) (Dahlberg et al., 2013; Dahlström, Teorell, 
Dahlberg, Hartmann, \& Lindberg, 2015). ${ }^{1}$ That professional bureaucracies (such as Japan and the U.S.) vary in tenure protections has been well established (Dunleavy \& Hood, 1994). Yet, similar variation exists in politicized states, with some (e.g. Greece) featuring strong and some (e.g. Dominican Republic) featuring weak tenure protections (figure 1).

Figure 1. Merit and Tenure in Patronage and Professional States ${ }^{2}$

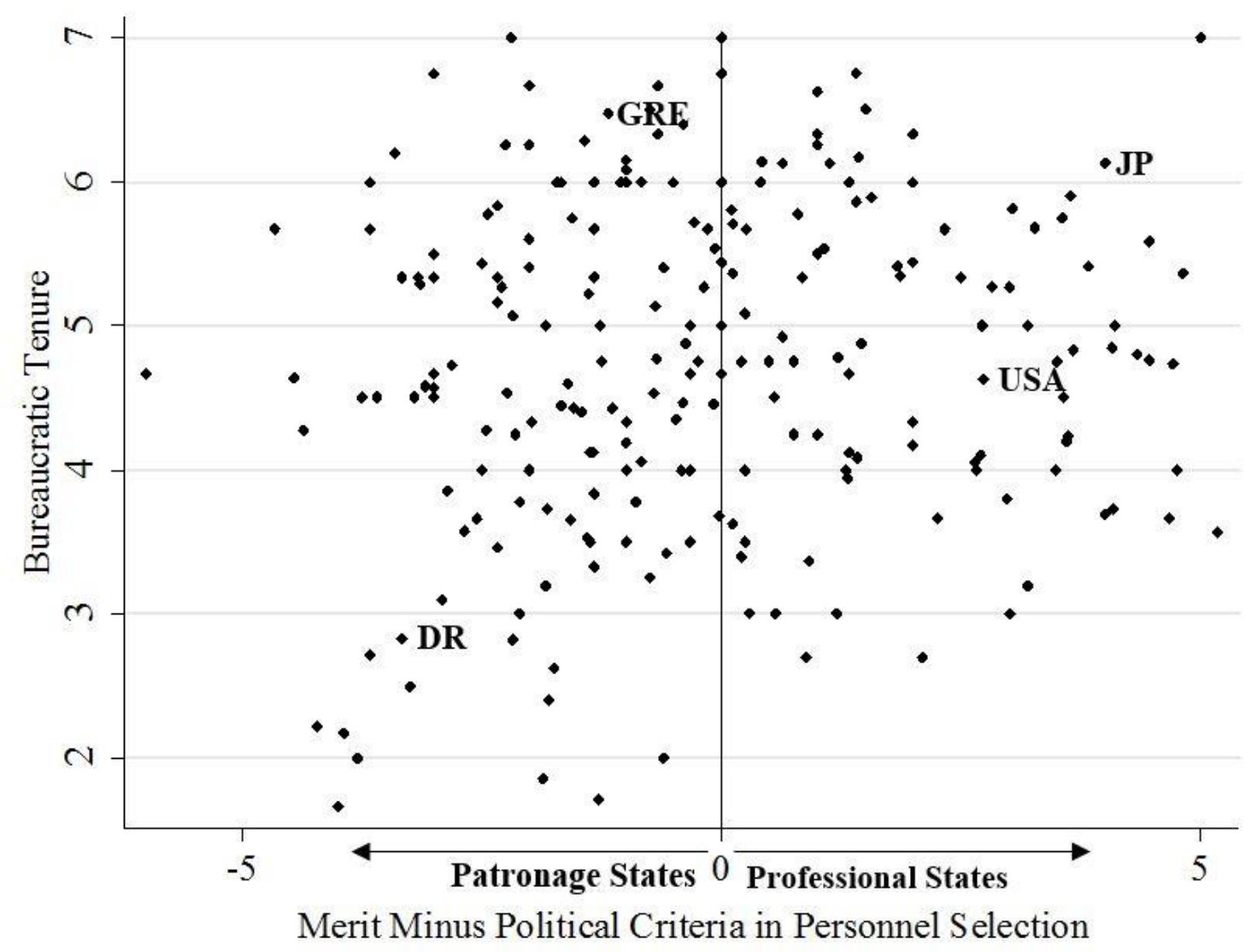

Sources: Dahlberg et al. (2013) and Dahlström et al. (2015)

\footnotetext{
${ }^{1}$ De facto merit and tenure are measured by the country expert survey questions "When recruiting public sector employees, the skills and merits of the applicants decide who gets the job?" and "Once one is recruited as a public sector employee, one stays a public sector employee for the rest of one's career?" (Dahlberg et al., 2013) The job stability question measures, as noted in the next section, an empirical implication of tenure protections rather than tenure itself.

${ }^{2}$ States in which political criteria trump merit criteria in personnel selection are classified as patronage states; professional states are those in which the opposite holds. Political criteria are proxied by the expert survey question "When recruiting public sector employees, the political connections of the applicants decide who gets the job?" (Dahlberg et al., 2013)
} 
Why do incumbents grant their patronage appointees tenure protections in some patronage states, yet not others? Political competition hypotheses offer a, seemingly, persuasive response: facing a potential exit from office, incumbents reform to insure themselves against hostile successors. After all, tenure - like many other institutional reforms - concurrently constrains incumbent and successor discretion over a state resource (the replacement of public officials with political appointees) which can be used for electoral advantage. In addition, tenure offers two further benefits: longer-run employment for party appointees and longer-run state control through loyal bureaucrats.

Yet, as we show in the next section, electoral uncertainty is associated with less tenure in patronage states. Why does electoral uncertainty not induce tenure reform?

We argue that reform is resisted under electoral uncertainty as it jeopardizes the electoral mobilization capacity of incumbents when they need it most: under contested elections. The causal mechanism goes as follows. Job stability reconfigures patron-client relations within bureaucracies: it frees appointees (bureaucratic agents) of dependency on their principals (patron-incumbents) for continued employment (by removing the spectre of dismissal); and material advancement (by enabling collective employee action for pay and promotions). Incumbents thus lose important incentive devices to ensure bureaucratic effort in administrative and electoral tasks. In patronage states, such effort is central to mobilizing the state and its resources in favour of incumbents. Tenure thus reduces incumbent capacity for electoral mobilization. Consequently, incumbents resist granting the gift of job stability to their own appointees in particular when elections are contested. The implication is clear: electoral uncertainty dis-incentives bureaucratic tenure.

These reform dis-incentives to ensure electoral survival, of course, are no longer in place where an exit from office is certain - such as after an electoral loss. Reform as insurance against hostile successors may well proceed in such contexts. Risk of and 
certain exit from office - as two potential empirical implications of electoral competition - thus yield contrary reform incentives. To avoid contradictory findings, scholars of institutional reform politics would do well to differentiate their effects.

As we detail below, suggestive cross-country data is consistent with this argument. Moreover, evidence from the Dominican Republic - which should have reformed according to electoral uncertainty hypotheses, yet did not - confirms the theorized mechanism linking electoral uncertainty with reform resistance. The analysis draws on tenure data and 30 semi-structured interviews. A rarity in the literature, the interviews provide first-hand data on the high-level political rationales for institutional reforms in a politicized state.

\section{Literature Review: Electoral Competition and Bureaucratic Tenure}

Tenure protections for public servants are permanent job contracts with protections against dismissals, in particular politically-motivated dismissals. Such protections are typically introduced through civil service or labour legislation, which either grant tenure to public servants by law or empower executive incumbents to extend tenure protections to public servants (see, for instance, Johnson \& Libecap, 1994). As also illustrated by tenure variation in figure 1, tenure protections are not dichotomous. Instead, they can vary in coverage - extending to some public servants and institutions, yet not others - and, as further detailed below, strength of enforcement. When introduced and enforced, tenure protections typically enhance stability and reduce turnover in bureaucracies. ${ }^{3}$

\footnotetext{
${ }^{3}$ This implication is not automatic, but may, on average, be expected. Instability in bureaucracies without tenure protections comes from voluntarily and involuntarily departures, including incumbents dismissing appointees of predecessors to appoint their own followers. By contrast, with tenure protections, instability only comes from employees leaving voluntarily. Yet, voluntary resignations are likely to be infrequent in patronage states, which characteristically feature wage premiums in most ranks (Finan, Olken, \& Pande, 2015).
} 
In the literature to-date, tenure protections remain a "somewhat puzzling institution." (Gailmard \& Patty, 2007, p. 875) Most studies of civil service reforms in patronage states associate reform with state capacity building, credible commitments to insulate bureaucrats and greater public goods provision. As such, they do well to account for the introduction of meritocratic recruitment - which prior studies link to lower corruption and economic growth (Dahlstroem, Lapuente, \& Teorell, 2012; Rauch \& Evans, 2000) - or the introduction of a civil service with merit recruitment and tenure. ${ }^{4}$

Variation in bureaucratic tenure without merit-based recruitment - i.e. tenure for patronage appointees - remains puzzling in light of these studies: ${ }^{5}$ lifelong employment for party appointees does not significantly enhance public goods provision (Dahlstroem et al., 2012; Rauch \& Evans, 2000). Consequently, it does not activate the mechanisms underlying studies linking civil service reform with enhanced public goods provision.

While tenure without merit thus, typically, does not build state capacity, tenure does - like many other institutional reforms - constrain incumbent and successor discretion over a state resource (the replacement of public officials with political

\footnotetext{
4 To illustrate, credible commitments to insulate bureaucracies from public goods- and investmentundermining political pressures are argued to induce reform (Miller, 2000; Nistotskaya \& Cingolani, 2016), as are: longer political time horizons enabling incumbents to reap the benefits of greater state capacity (Lapuente \& Nistotskaya, 2009); electoral competition leading to greater government accountability for public goods performance (O'Dwyer, 2006); and equal access to patronage incentivizing parties to forsake patronage while gaining electoral credit for greater public goods provision (Geddes, 1991).

${ }^{5}$ Studies of tenure variation in professional bureaucracies - which this paper does not shed further light on - can, similarly, not explain tenure variation in patronage states. In professional bureaucracies, concerns with government performance and bureaucratic demand have been advanced as reform explanations. Performance can be enhanced by tenure where it creates an 'esprit de corps' around impartial and committed behaviour or enhanced bureaucratic incentives to invest in expertise (Gailmard \& Patty, 2007; Rauch \& Evans, 2000). Bureaucratic demand for tenure may cause reform where bureaucrats are able to seek protection from interest groups or exploit legislative-executive rivalries (Carpenter, 2001; Johnson \& Libecap, 1994). Yet, these explanations are unlikely to travel to patronage states. Absent tenure protections, patrons may simply dismiss appointees seeking to strip patrons of dismissal powers (see Johnson \& Libecap, 1994). Moreover, tenured political appointees are unlikely to develop 'esprits de corps' or face enhanced incentives to invest in expertise (Dahlstroem et al., 2012; Rauch \& Evans, 2000).
} 
appointees) which can be used for electoral advantage. As such, it lends itself to political competition hypotheses. Political competition hypotheses argue that competition is a “principal incentive" or "driving force" for reform (Geddes, 1996, p. 190; Moe, 1989, p. 267). By contrast, certain permanence in office is argued to dis-incentivize reform: "politicians in one-party states [see] little reason to abandon patronage," "because they alone stand to benefit.” (Grzymala-Busse, 2003, p. 1131; Ruhil \& Camões, 2003, p. 34) Three mechanisms to link political competition with civil service reform which could account for tenure have been posited in prior studies: insurance, state control and partisanship.

Mirroring insurance arguments for other institutional reforms, Ting et al. (2013) posit that political competition incentivizes civil service reforms (including tenure) as an insurance mechanism against potentially hostile successors. Successor governments may no longer replace the incumbent's appointees with appointees of their own. As such, they lose (part of) their ability to trade jobs for political support. Tenure can thus protect incumbents from uneven playing fields in future elections in case they lose office.

Beyond insurance, tenure offers two further, more idiosyncratic benefits to electorally uncertain incumbents. First, tenure enables incumbents to lock in political agendas and secure control of state institutions over longer periods should hostile successors take over (state control argument) (Horn, 1995; see also Silberman, 1993). Tenure offers this benefit to incumbents as it enhances the likelihood that bureaucrats loyal to incumbents remain in office. Second, "blanketing in" party appointees through tenure protections secures their long-term employment and thus increases the value of appointments to them (Ruhil \& Camões, 2003, p. 34). This in turn may evoke longer-run attachment and reciprocal electoral support to the incumbent party (partisanship argument). As Geddes (1991, p. 387) puts it, “extending ... job guarantees to larger 
numbers of employees ... pose[s] no problem ... since they bring electoral benefits from grateful employees."

In sum, political competition is argued to enhance uncertainty over future political control by increasing the risk of exit from office - which in turn enhances the attractiveness of tenure reforms to secure insurance against hostile successors, long-run state control and long-term employment for party affiliates.

If these studies held true, however, almost all states with politicized recruitment and competitive elections should have introduced tenure protections. In competitive electoral contexts, incumbents risk exit from office recurrently. Yet, in the 51 countries included in the Quality of Government Expert Survey which are characterized by politicized recruitment and formally competitive elections (henceforth: patronage democracies), tenure is lower in countries with tighter margins of majority (see fitted curve in figure 2). Vice versa, greater vote shares of governing parties are associated with more tenure $(\mathrm{r}=0.13){ }^{6}$ This positive relationship holds, albeit not at statistically significant levels, when controlling for other plausible tenure determinants, such as per capita incomes, rule of law, education, trade openness and foreign aid. ${ }^{7}$

\footnotetext{
${ }^{6}$ Ideally, the risk of exit from office would be measured by incumbent beliefs of the probability of remaining in office after an election. Yet, large-n data of such beliefs is unavailable. Following other studies (see, for instance, Berliner \& Erlich, 2015), figure 2 relies as a second-best on electoral competitiveness measures. This paper's argument - that the effects of electoral uncertainty differ from those of certain exits from office - of course underscores the shortcomings of such measures to explain institutional reform.

${ }^{7}$ Results available upon request. The absence of credible panel data on tenure protections preclude inferences beyond these conditional correlations.
} 


\section{Figure 2. Electoral Uncertainty and Bureaucratic Tenure in Patronage} Democracies $^{8}$

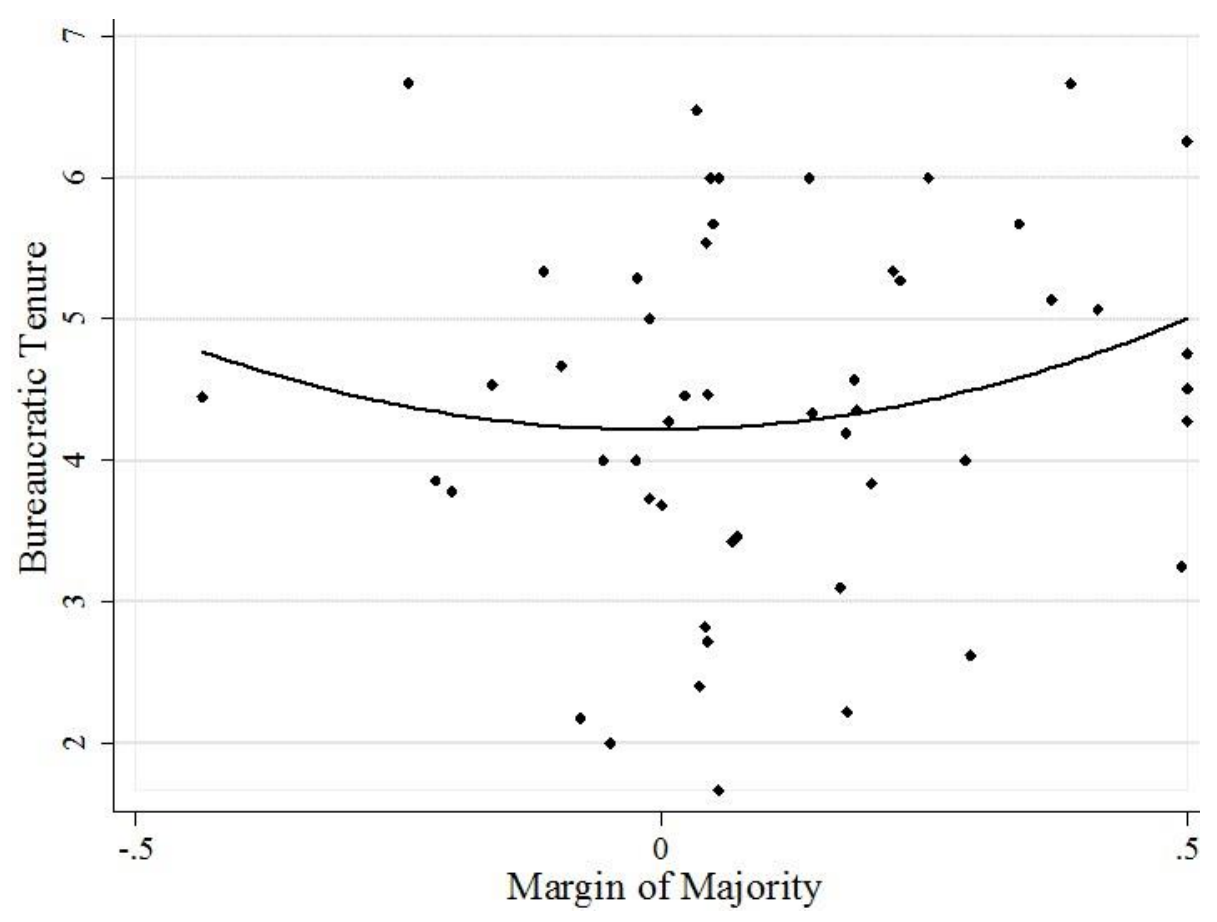

Data sources: Dahlström et al. (2015) and Beck et al. (2001)

The conundrum these suggestive conditional correlations point to is clear. Why would incumbents resist an institution ostensibly benefiting their own followers and themselves while harming potentially hostile successors when facing a potential exit from office? In other words, why does electoral competition appear to induce institutional reform resistance rather than reform? The next section develops a theoretical argument to resolve this conundrum.

\footnotetext{
${ }^{8}$ Following Ingram (2013), figure 2 operationalizes electoral uncertainty with the government's legislative majority distance ( 0 in figure $2=50 \%$ seat share).
} 


\section{Theoretical argument: Electoral Uncertainty and Tenure Resistance}

As shall be argued, electoral uncertainty dis-incentivizes incumbents to introduce tenure as tenure impairs incumbents' electoral mobilization capacity when they need it the most: in contested elections.

To develop this argument, political patrons (principals) and their appointeeclients (bureaucratic agents) are treated as rational actors: they exchange benefits iteratively and inter-temporally to mutual advantage. This instrumental principal-agent perspective follows most recent studies of patron-client relations (Hicken, 2011). Benefits to bureaucratic agents in patronage states extend principally to public sector jobs and their wage and non-wage benefits. In exchange, bureaucratic agents exert effort in administrative and electoral tasks to support their principal, the patron-incumbent. Such patron-client exchanges are frequently central to tilting elections in favor of incumbents in patronage states (Folke, Hirano, \& Snyder, 2011).

Consider how tenure protections reshape incentives to engage in these exchanges and enhance principal-agent problems in patron-client relations (figure 3). Tenure does away with dependency of bureaucratic agents on the goodwill of their patron principals for: continued employment by removing the spectre of dismissal; and material advancement by facilitating unionization and thus collective action for generalized pay (rises) and promotion. ${ }^{9}$ Patron principals thus lose (part of their) power over bureaucratic employment, careers and remuneration. Vice versa, bureaucratic agents gain in autonomy and thus leeway to shirk and "take actions consistent with their own wishes." (Carpenter, 2001, p. 4) ${ }^{10}$ Greater autonomy from patron principals lowers responsiveness (cf. Frant,

\footnotetext{
9 Without tenure, dismissal powers of patron principals preclude unionization and collective action antagonistic to their interests.

${ }^{10}$ Note that this paper thus sheds light on bureaucratic autonomy at the level of individual bureaucrats, rather than autonomy of bureaucratic organizations from elected officials (Carpenter, 2001).
} 
1996): bureaucratic agents face fewer incentives to exert effort in, first, administrative and, second, electoral tasks.

The negative effect of tenure on bureaucratic effort in response to administrative demands was, of course, central to New Public Management critiques of Weberian bureaucracies (Dunleavy \& Hood, 1994). In patronage states, the loss of bureaucratic effort in administrative tasks has immediate repercussions for incumbent electoral mobilization capacity. Bureaucratic agents frequently politicize administrative tasks and public service provision, delivering and favouring (prospective) electoral supporters of the incumbent in exchange for pledges of political support (Oliveros, 2016).

Analogously, tenured bureaucrats no longer need to vote and campaign for their patron principals to safeguard employment and material advancement. Principals may no longer withdraw employment and (part of) material advancement where bureaucratic fail to do so (Robinson \& Verdier, 2013). Moreover, the career fates of bureaucratic agents are no longer tied to the electoral fates of patron incumbents, enhancing goal divergence between patron principals and bureaucratic agents. Without tenure, by contrast, campaigning is in the best interest of bureaucratic agents to preclude the election of hostile successors. Unsurprisingly then, tenured employees are found to provide fewer campaign services (Oliveros, 2013; Oliveros \& Schuster, 2017).

Tenure thus enhances the autonomy of bureaucratic agents from patronprincipals and deprives bureaucratic agents of incentives which are crucial to ensure bureaucratic effort in targeting state goods to voters and participating in electoral campaigns. ${ }^{11}$ Ironically, politically-recruited bureaucrats thus reciprocate the gift of tenure

\footnotetext{
${ }^{11}$ Incumbents may, of course, count on other selective incentives or affective ties with appointees to ensure responsiveness. The argument is, thus, of ceteris paribus nature: with tenure, incumbents lose part of their inducements to ensure responsiveness and are less able to mobilize electoral support. Where incumbents count on ample other inducements or affective ties, this effect is more subdued.
} 
with greater oblivion to the political needs of their political principals. This jeopardizes part of the government's electoral mobilization capacity.

Reduced electoral mobilization capacity in turn enhances the likelihood of electoral defeat in contexts of electoral uncertainty. Electoral uncertainty is understood here as incumbent government uncertainty over a re-election outcome. Uncertainty is higher in closer electoral races with smaller and less predictable expected margins of victory or loss. In such contexts, incumbents perceive a greater risk of a potential exit from office. Uncertainty is lower for incumbents whose electoral support is sufficiently low (or high) and predictable for exit (or permanence) from office to be almost certain. ${ }^{12}$

When facing electoral uncertainty and thus risking exit from office, incumbent politicians face particular dis-incentives to introduce or expand tenure: tenure would reduce the electoral mobilization capacity of incumbents when they need this capacity the most to remain in office and avoid electoral defeat. This immediate reform dis-incentive to favour political survival in office then trumps longer-run benefits from reform, such as insurance against hostile successors. ${ }^{13}$

\footnotetext{
${ }^{12}$ Formally, uncertainty is higher where the incumbent's expected probability of victory is closer to 0.5 and the variance of this expected probability is higher. By contrast, electoral uncertainty is lower where the incumbent's expected probability of victory is closer to 1 (certain electoral victory) or 0 (certain electoral loss) and its variance is lower (cf. Berliner \& Erlich, 2015; Shepsle, 1972).

${ }^{13}$ More precisely, incentives are tilted against reform when the expected probability of victory is sufficiently close to 0.5 (and distant to 0 ) and its variance sufficiently high that immediate political survival incentives outweigh discounted longer-run reform benefits, such as insurance against hostile successors.
} 


\section{Figure 3. Causal Mechanism: Electoral Uncertainty and Tenure Resistance}

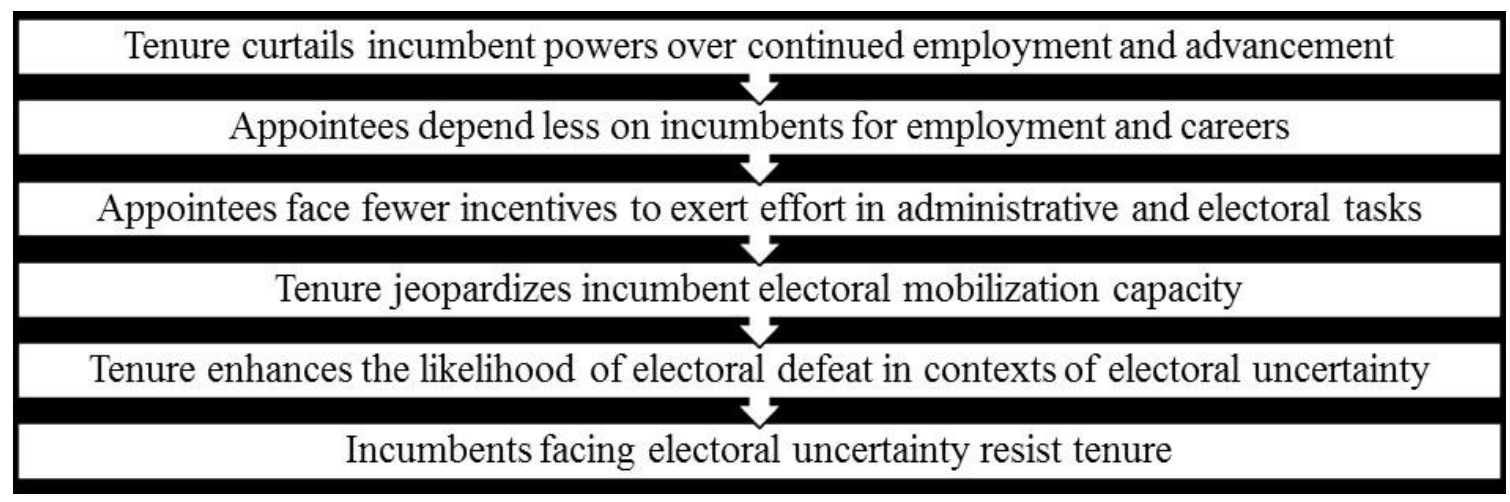

This argument, of course, only applies if there is electoral uncertainty - and thus a risk of electoral defeat. Where an exit from office is certain - such as after an electoral loss - the mechanisms lose force. This differentiation is important as prior studies of institutional reforms had, as noted, frequently confounded the effects of a risk of and certain electoral loss. To illustrate, Ting et al. (2013, pp. $364 \& 379)$ argue concurrently that reform occurs with ,,an imminent election loss“ and when „future elections [are] competitive."Yet, while reform incentives emphasized in prior studies - such as insurance against hostile successors - may well be in place with certain exits from office, a contrary incentive - to resist reform - is in place with electoral uncertainty - and thus a risk of exit from office - if this paper's argument holds true.

In other words, this paper's argument about the two-edged sword of political competition challenges predictions of prior studies in contexts of electoral uncertainty; the empirical analysis in this paper will thus focus on providing evidence for this side of the argument. At the same time, the two-edged sword argument builds on and shares reform predictions of prior studies where exits from office are certain. The paper does not provide additional empirical evidence for this side of the argument: evidence in prior studies and examples for such reforms are abundant. In the historic U.S. case, for instance, 'blanketing 
in' [i.e. tenuring] of employees through Presidential decrees frequently occurred under lame duck Presidents, after electoral defeat and before a new administration took office (Johnson \& Libecap, 1994). ${ }^{14}$ Other institutional reforms which constrain incumbent discretion exhibit similar patterns. Berliner and Erlich (2015, p. 111 \& p. 126), for instance, find a "disproportionate tendency for [transparency] laws to be passed during" "lame duck periods after elections have been held but before new elected officials have taken office" in Mexican states.

This paper thus nuances predictions about the effects of political competition, underscoring its two-edged nature. At the same time, as in most prior political competition studies, nothing in the argument points to tenure reform incentives where permanence in office is certain (see, e.g., Geddes, 1996; Grzymala-Busse, 2003; Horn, 1995; Moe, 1989; Ruhil \& Camões, 2003; Ting et al., 2013). The argument does implicate, however, that incumbents face fewer reform dis-incentives in contexts of certain re-election relative to electoral uncertainty. Where permanence in office is certain - and incumbents need not fear electoral defeat with tenure - the hypothesized tenure reform dis-incentive due to losses of electoral mobilization capacity has less weight. In the absence of other reform incentives, however, incumbents in such contexts may still resist losses in electoral support due to tenure - even if such losses are not critical to re-election.

\footnotetext{
${ }^{14}$ Similarly, incumbents, at times, empower bureaucratic agents to unionize and protect tenure through collective action where exits from office are certain. To illustrate, in Paraguay, 150 unions were formed after the Colorado Party lost the 2008 election, before opposition candidate Fernando Lugo took office. Subsequently, these unions mobilized against dismissal attempts by Lugo (Schuster, 2015).
} 


\section{Method and Data}

To assess the competing mechanisms linking electoral uncertainty with tenure, this paper relies on a case analysis. Contrary to a large-n study, a case analysis can provide insights into the rationales of political actors contemplating tenure reform under electoral uncertainty, and the congruence of these rationales with theorized mechanisms.

To provide (some) confidence in the generalizability of inferences from a single case, a particularly challenging case was selected: one in which reform was, according to prior theories, 'most likely': the Dominican Republic (DR) under the Dominican Liberation Party (PLD) Government of President Leonel Fernández (20042012). The PLD administration presided over an archetypical patronage state with electoral uncertainty. At the same time - and rather exceptionally - it faced vocal societal demand for tenure reform. Tenure thus offered electoral benefits beyond those posited in electoral uncertainty studies. If prior theories held true, reform should have thus proceeded. By contrast, if this paper's argument held, the PLD administration should have resisted reform.

In the DR, primary and secondary data on the dependent variable, rival explanations and mechanisms were collected. The dependent variable measurement comprised data collection on tenure in law and practice. The rationale is simple. Credible tenure protections require both legal tenure protections and incumbent respect for these legal protections. In the weak rule of law contexts characteristic of patronage states, legal tenure protections, of course, need not constrain incumbents. Civil service - and other institutional reform - legislation is often disregarded in politicized states (Grindle, 2012; Schuster, 2017). How then can tenure credibly constrain incumbents and their successors in weak rule of law contexts? 
As with other institutional reforms (cf. Berliner, 2014, p. 482-483), two mechanisms can cause institutional inertia in such contexts. First, large-scale violations of legal tenure protections are likely to generate attention and criticism, thus imposing domestic and international audience costs on incumbents (cf. Lohmann, 2003). Second, tenure protections generate a new and potentially large constituency for their enforcement: tenured public servants. Their ability to enforce tenure protections, however, may be expected to hinge upon their unionization - and thus collective action capacity to impose political costs on government through strikes and other measures in response to tenure reversal attempts.

As a result, legal tenure protections by no means ensure bureaucratic job stability in patronage states, but make dismissals of employees more politically costly to incumbents than they would otherwise be. These political costs - and thus the credibility of tenure as a constraint - increase with employee unionization and electoral relevance of audience costs.

With this in mind, field research was not limited to a review of tenure laws, but also included information requests to state agencies about the number of tenured employees, and 30 semi-structured, high-level stakeholder interviews on the enforcement of tenure protections, the tenure reform process and political considerations in key reform decisions.

Exceptionally for studies of politicized bureaucracies, the paper thus sheds light on the thought processes of stakeholders considering institutional reforms under electoral uncertainty. Concomitantly, it provides primary evidence for the congruence between competing theoretical mechanisms and actor rationales and actions.

To ensure responses from diverse stakeholders, interviewees were sampled purposively. Publicly known reform participants and observers were sampled first. 
Snowballing then led to less visible stakeholders. Sampling was repeated until interview data covered reform processes and rationales and was triangulated through responses from distinct stakeholders: politicians (legislators and (vice)ministers) (20\% of respondents), bureaucrats and advisors (30\%), and actors outside the state (50\%), including donor officials, NGO analysts and local academics.

\section{The Dominican Case: Electoral Uncertainty and Tenure Resistance}

The DR is a middle income country and the largest economy in Central America and the Caribbean. After a first democratic alternation in 1978, a constitutional reform in 1994 ended serious electoral fraud in electoral contests and permitted formally free and fair elections (Marsteintredet, 2010).

As noted, the case analysis focuses on the PLD Government of President Fernández (2004-2012). After Fernández’ 2004 election, the PLD remained electorally dominant in 2004-2008. In 2008-2012, however, the PLD began to face increasing electoral uncertainty. In this period, case evidence suggests, at first sight, that the DR was a poster child case for previous political competition hypotheses. Facing a potential exit from office, the PLD administration was, as detailed below, keenly aware of the political benefits offered by tenure protections: insurance against patronage access for an opposition party successor; longer-term employment for PLD members; and continued PLD control over parts of the state. In addition, reform would have placated civil society demands. Nonetheless, the PLD resisted significant tenure reform.

Case evidence suggests this paper's argument was at cause. Tenure would have deprived the PLD of power over dismissals and, intermittently, material advancement of public servants. This was feared to reshape patron-client relations in the Dominican bureaucracy, lowering the dependency of bureaucratic agents on the PLD administration 
- and thus their responsiveness to the PLD's administrative and electoral campaign demands. Bureaucratic responsiveness and mobilization in turn safeguarded an incumbency advantage in tightly contested elections. Facing this immediate electoral disincentive, the PLD administration denied PLD members in the bureaucracy the gift of tenure.

These conclusions are derived in three steps. First, the case's 'most likely' characteristics from the viewpoint of prior theories are detailed: a patronage state with electoral uncertainty and societal demand for tenure. Subsequently, the dependent variable - tenure reforms - is measured. Lastly, the mechanisms incentivizing and dis-incentivizing tenure reforms are assessed.

\section{Scope Conditions for Prior Theories: Electoral Uncertainty and Societal Demand.}

From the viewpoint of prior theories, tenure should have occurred in the DR: the PLD administration governed an archetypical patronage state, faced electoral uncertainty in 2008-2012 and a societal coalition demanded reform. Consequently, and somewhat ironically, tenuring PLD affiliates in the bureaucracy provided public opinion benefits to the administration.

The DR has historically been a patronage state and remains so today. Dictatorship and authoritarian rule in the $20^{\text {th }}$ century concentrated patronage powers in the Presidency (Espinal, Morgan, \& Hartlyn, 2010). Democratic reforms in 1978 and 1994 brought formally free and fair elections, but not patronage reform in practice. Despite merit requirements in the 1991 and 2008 civil service laws, merit examinations supervised by the Ministry of Public Administration (MAP) accounted for only one percent of vacancies (2004-2012) (MAP, 2013a). The remaining posts were largely filled through party- 
political appointments. In fact, in an in-depth expert survey of bureaucratic politicization in 22 new democracies in Latin America, Africa and Eastern Europe, the DR ranked top, with the most politicized public sector recruitment (Kopecky et al., 2016).

Similarly, few employees counted on tenure. The tenure of 'administrative career personnel' was, per the country's 1991 civil service law, legally protected. Yet, as detailed below, hardly any employees were incorporated into the 'career'. Moreover, legal tenure protections were not consistently respected in practice. Not unionized, tenured employees lacked collective action capacity to protect themselves from dismissals: in 2004, for instance, over 20 percent of tenured career staff was dismissed without compensation (Participación Ciudadana, 2007). ${ }^{15}$ These dismissals were paralleled by mass turnover in the bureaucracy with governing party change, locally known as 'steamrolling' (aplanadora). To illustrate, in 2008, 60 percent of public servants had been employed since Fernández’ 2004 election (Iacoviello, 2009).

Control over these patronage powers provided the incumbent with great electoral advantage. The DR ranks as the third most clientelist country in a global expert survey: clientelism - the exchange of state benefits for political support - is central to electoral mobilization (Kitschelt, 2014). Patronage in turn is central to clientelist vote mobilization: the DR's electoral “context has, at its centre, employment offers from the state." (Interview A). In exchange for jobs, public employees vote for the incumbent; attend electoral campaign events; run neighbourhood-level political machines; participate in vote buying; donate a percentage of their salary to the party; and channel other clientelist

\footnotetext{
15 Turnover of tenured administrative employees relative to tenured and unionized professionals - doctors and teachers - is illustrative: only unionization ensured consistent respect for tenure protections. To illustrate with the case of doctors: "especially at the beginning of governments, hundreds of doctors are - just like administrative career employees - dismissed ... with the Medical College [the doctor's union] needing to undertake road blocks and strikes for them to be reinstated." (Participación Ciudadana, 2007, p. 25) By contrast, tenured but non-unionized administrative employees could not challenge dismissals through collective action.
} 
goods provided by the state bureaucracy to governing party supporters (Gonzalez-Acosta, 2009). The 2012 election was no exception (Meilán, 2014).

Drawing on this electoral advantage, the PLD was electorally dominant in 2004-2008. Fernández had been elected in a landslide in 2004, with a 23 percent margin over the previous incumbent who had been discredited by a large-scale financial crisis. In the 2008 Presidential elections, the PLD retained its dominance, with a 14 percent victory margin for Fernández (Benito Sanchez, 2010). Electoral dominance is also reflected in public opinion data: a clear majority of the population (57\% to $61 \%$ ) rated the work of the Fernández administration as good or very good in 2004-2008 (LAPOP, 2017; figure 4).

During the 2008-2012 term, however, electoral support for the PLD started to erode - and the PLD administration began to face electoral uncertainty. Corruption scandals, failures in key public services and mounting macroeconomic instability - with the debt-to-GDP ratio rising by over one-third in 2008-2012 - threatened the PLD's grip on power (World Bank, 2014). A potential exit from office in the 2012 presidential elections was palpable. The percentage of the population rating the work of the administration as good or very good plummeted from 61 percent in 2008 to 47 percent in 2010 and further to 37.5 percent in 2012 (LAPOP, 2017; figure 4); and several polls predicted an opposition party (PRD) victory in the run-up to the election (Meilán, 2014). While incumbent expectations about probabilities of victory are not directly observable (cf. e.g. Berliner, 2014), the triangulation of public opinion, poll and election (see below) data points to a generalized sense of electoral uncertainty in the country. In the end, the 
PLD clung to Presidential power in a tight race, with its candidate winning with 51 percent, relative to 47 percent for the PRD candidate. ${ }^{16}$

Incumbent uncertainty about re-election implicated uncertainty about future patronage control. The DR features - as many other patronage states (see, among many, Rose-Ackerman, Desierto, \& Volosin, 2011) - a hyper-presidentialist system. The Presidency monopolizes control over patronage and policy making (Author, 2016). According to some observers, the country could "perfectly live without Congress." (Interview B). Competition between two major parties further reinforced the 'winner takes all' nature of the 2012 presidential elections. The key scope condition of prior theories was thus in place: the incumbent party risked exit from office and, with it, future patronage access and the resulting electoral advantage.

Quite exceptionally, the PLD administration faced an important additional reform incentive: a broad civil society-business-donor coalition - the Participatory AntiCorruption Initiative (IPAC) - sought tenure reform. Concurrent to the increase in electoral uncertainty in 2010-2012, IPAC brought together 260 societal stakeholders, including in a working group on civil service reform (World Bank, 2014). Its targets included the number of tenured employees. As an NGO analyst (Interview C) explains: "the form in which the work of the Ministry [of Public Administration] has been measured ... is quantitative ... 'How many did they incorporate this year?'” Indiscriminate societal support stemmed in part from the DR's (lack of) civil service reform history: "This topic was completely abandoned ... [It was] not even on the agenda. For a civil society which had cried out [about it] ... and the government ignored it ... to suddenly see that there is a

${ }^{16}$ In 2012, the constitution precluded Fernández from seeking re-election. The PLD instead fielded Danilo Medina who had, until 2006, served as Fernández' Minister of the Presidency; Fernández' wife ran as VicePresident. 
will to incorporate public servants into a [tenured] career ... It was like: 'now we cannot criticize a process which we have sought for years'." (Interview D) Societal demand implied public opinion benefits from reform: "a head of the institution is interested that every year the public opinion says: 'ah, but this official strengthened the institution, because look how many new employees he incorporated into the career.'” (Interview E)

The societal focus on quantity implicated that the PLD administration was - as evidenced below - unconstrained in deciding which employees to tenure. The PLD administration could thus reap public opinion benefits from tenuring PLD appointees of its choosing: "they had a free hand in implementing something which supposedly was good and which civil society supposedly demanded.” (Interview F)

Facing electoral uncertainty and societal demand for reform, the PLD government should have - from the viewpoint of prior theories - counted on tenure reform incentives. President Fernández' PLD government certainly also had the ability to reform. Civil service legislation empowered the executive to extend tenure. Moreover, the PLD held legislative majorities and was characterized by "subordination to [Fernández'] leadership" at the time (Interview F). The PLD administration could have thus extended tenure protections if it wished to. Despite this ability and, seemingly, reform incentives, however, the PLD administration chose to advance tenure hardly at all.

\section{Measuring the Dependent Variable: Tenure Reforms in the Dominican State.}

In 2004-2012, tenure did not advance substantively in practice. The number of employees without tenure increased, and unionization did not advance. Despite legal reforms, the PLD administration could thus largely continue to dismiss public servants at will.

On paper, the DR saw a "revolution" in bureaucratic reform (Interview G).

A 2008 public service law prohibited unjustified dismissals of public servants with 
administrative career status, and a 2010 reform enshrined these protections in the constitution (Interview H). Yet, the PLD administration granted hardly any employees this tenured administrative career status. Through presidential decrees, only 2,456 public servants were tenured per year in 2004-2012. ${ }^{17}$ In comparison, public employment increased by over 20,000 per year to reach 480,000 by the end of 2012 (Contraloria General de la Republica, 2013). The number of employees without tenure thus increased under Fernández. Moreover, annual tenure incorporations remained largely flat with greater electoral uncertainty in $2008-2012(+2,413$ per year) relative to $2004-2008(+2500$ per year) and, much more importantly, minimal in number. Gross tenure incorporations never exceeded $1.1 \%$ of public employees per year in 2004-2012 (figure 4$).^{18}$

Figure 4. Tenure Incorporations and PLD Public Opinion Support

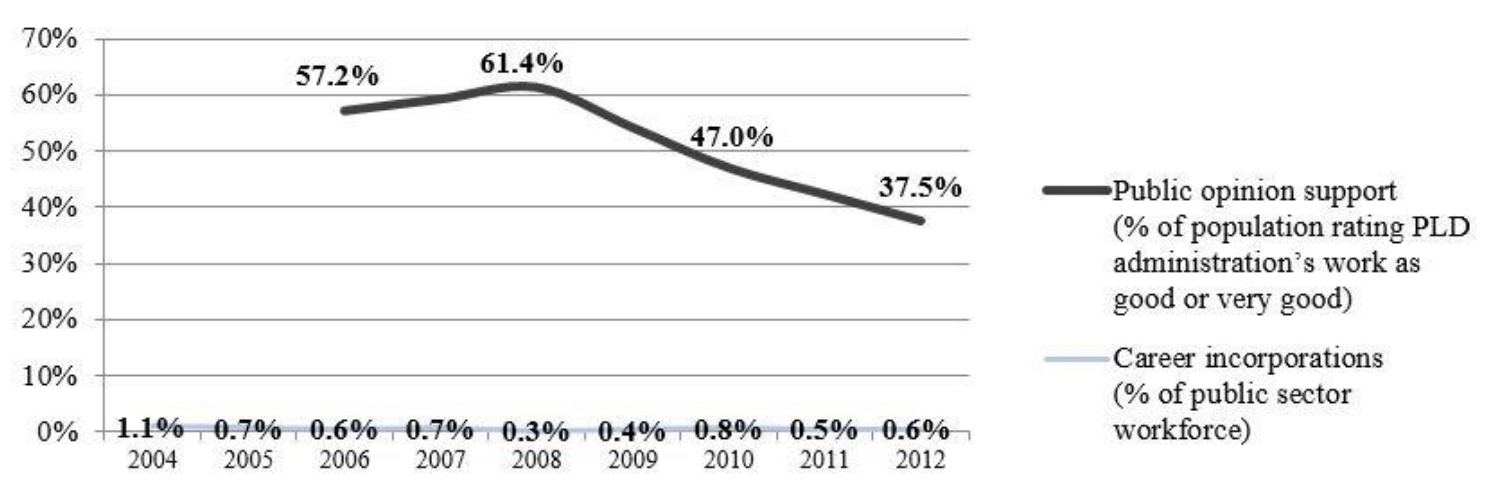

Data source: MAP (2013b) and LAPOP (2017)

The few administrative employees who were tenured, moreover, lacked collective action capacity to protect themselves from dismissals: unionization did not

\footnotetext{
17 The terms career personnel and tenured personnel can be used interchangeably in the Dominican case. "Career" incorporation simply denotes tenure protections: patronage continues to govern recruitment and career paths remain undefined.

${ }^{18}$ Note that this gross number overestimates tenure expansion as it does not account for resignations, retirement or redundancies of tenured staff.
} 
advance. While 44 Associations of Public Servants were formally created to comply with the 2008 public service law, these did not develop collective action capacity: "What have they done? ... The President [Medina], when he took office, for example, said: 'all public sector salaries are frozen.' Have you heard that any association has said anything? ... If they were effective associations, the first thing they would have said to the President ... is ... why will you sacrifice us by not granting us a salary increase in the next two years ... [Yet,] it passed without any type of complaint." (Interview I) As a result, their "impact ... has not been very relevant." (Interview J)

Without unionization, enforcement of legal tenure protections was not assured. Rule of law is weak in the DR; the country ranked in the $30^{\text {th }}$ percentile in the World Bank's Rule of Law indicator in 2012 (World Bank, 2013). Moreover, law enforcement is largely subjugated to Presidential authority. Presidents appoint to - and thus control - the judiciary and audit institutions. Presidents may thus often violate legal protections at will. Consequently, as a legislator (Interview K) put it, "here it does not matter if you are in the career or not to dismiss you ... because where will you turn to afterwards?" An NGO analyst (Interview L) adds: "even if somebody is incorporated in the career, if they want to dismiss him, they will do it ... The fact that a law prohibits it does not mean it will not be done."

While tenure protections were thus not consistently enforced, they did impose some constraint on the incumbent. In fact, in surveys, tenured employees sensed that they were more protected from arbitrary dismissals than other public servants, even if only marginally; and were, as detailed below, less likely to campaign for the incumbent (Oliveros \& Schuster, 2017). Yet, as noted above, hardly any employees were granted this tenure status and unionization to strengthen tenure enforcement was precluded. Reform in practice thus remained minimal. 
That an electorally dominant incumbent in 2004-2008 did not advance significant reform is congruent with prior political competition studies, which note a lack of reform incentives for dominant parties. Yet, counter to prior studies, reform hardly advanced during a period of high electoral uncertainty in 2008-2012. The next two sections will account for this conundrum, juxtaposing tenure reform incentives with dis-incentives under electoral uncertainty.

Assessing Prior Theories: Electoral Uncertainty and Tenure Reform Incentives.

As noted, political competition is hypothesized to incentivize tenure through three mechanisms in prior studies: partisan employment; state control; and insurance. In the DR, all three mechanisms were at play.

The first mechanism - and benefit of tenure - was keenly recognized by PLD officials: long-term employment for governing party appointees. As a Controller General (Interview E) under Fernández admits, “in the Dominican Republic, the administrative career is a political resource to protect the governing party. What this is to say is that officials involved in the career, to protect their party comrades, place them in the career so that if a change in ... the party in power is produced, the dismissal of these career employees is made more difficult." Tenure thus also represented an additional form of patronage dispensed by PLD leaders to evoke gratitude and subsequent political support. As an Advisor in the Ministry of the Economy (Interview M) explains, career incorporation "is a concession they give you ... a gift from the Minister." An NGO analyst (Interview N) adds: "In our reality, this can be sold ... as a gift ... I can tell a public servant: look ... I will incorporate you into the career ... this means that you will have permanence here ... and in some time you will have a pension. So this public servant, given how the 
matter is presented ... perceives the career incorporation not like a normal, legal, natural process but as a favour. So this favour I then owe to who made the offer."

Reform process observations are congruent with two empirical implications of this mechanism: tenure was extended selectively and to governing party appointees. Most tenured employees were PLD recruits since 2004. The corresponding percentage reached 86 percent in 2012, for instance (Collado, 2012). As a result, the process "is limited just to your people but gives them stability." (Interview O) Within this group of party recruits, authorities could determine who to evaluate for career incorporation. While, formally, all eligible personnel were to be evaluated, authorities could oblige employees to renounce from evaluation by threatening dismissal (Interview M). Beyond political 'permission', tenure was conditioned in practice on occupying a career position and complying with minimum educational requirements. Competence was not strictly required. Candidates scoring zero in the technical test, for instance, could still be tenured (Collado, 2012). Even a Director in the Ministry of Public Administration (MAP) - the Ministry spearheading the reform - then concludes that "many people are included who really should not be career public servants." (Interview P)

With selective tenuring of PLD appointees, the second mechanism in prior studies was activated: the PLD government could secure state control beyond its terms in office by tenuring loyal affiliates in key positions: "you are generating loyalties of people whom you guarantee this stability which transcends beyond the period in which you will be there ... If you manage to concentrate these loyalties in distinct institutions, it can be a form of controlling the subsequent ones who come ... A Minister would say 'well, if I leave here the director of procurement as well as the directors of human resources and finance, any new minister may come, but I am the one who is controlling ... the key areas of the institution.” (Interview Q) 
Lastly, tenure also offered the benefit of insurance against an opposition party successor. Tenure would reduce the number of public sector jobs a 2012-2016 opposition party President could exchange for political support. In fact, the principal opposition party PRD feared just that. In the 2012 election campaign, PRD leaders denounced that the PLD was tenuring its appointees in order to protect governing party affiliates and prevent PRD affiliates from replacing them and being appointed to state positions in case of a PRD electoral victory (El Día, 2012).

In conclusion, the PLD administration was highly cognizant of the political benefits tenure offered in a context of electoral uncertainty and societal reform demand. Nonetheless, it only conceded reform on paper to placate civil society demand (Schuster, 2014). Significant reform in practice - and thus a credible constraint on the PLD's dismissal powers - was resisted. As argued next, tenure reform incentives were overwhelmed by reform dis-incentives in an electorally uncertain context.

\section{Patrons against Clients: Electoral Uncertainty and Tenure Reform Dis-Incentives.}

Consistent with theoretical expectations, the PLD administration resisted tenure as it feared losing electoral mobilization capacity with reform in an electorally uncertain context.

The executive's resistance was instrumental to bringing reform to a standstill. The President authorized reform in law and constitution, yet deliberately not the necessary financial resources to implement reform, the "power to enforce it" (Interview B), and the requisite political directive for ministerial compliance: "If there was a precise directive by the President ... to all the ministers via a decree, ... all ministries [would be] ... complying ... 'Why does the President ... not produce a ... decree?' ... Because of a 
political calculation obviously." (Interview C) Unionization to enable employees to collectively act to protect tenure was, similarly, resisted. As a Director in the Ministry of Health (Interview R) explains, "if it was identified that they were forming a group, the leaders of the union would be dismissed." A Vice-Minister of Finance (Interview S) adds: "there were never efforts to unionize. I would have opposed it ... The first one that speaks out, you give him a grave misconduct note and you dismiss him."

As theorized, the PLD government's tenure resistance was motivated by the electoral risk tenure presented in a competitive electoral context (figure 5).

Figure 5. Causal Mechanism in the DR

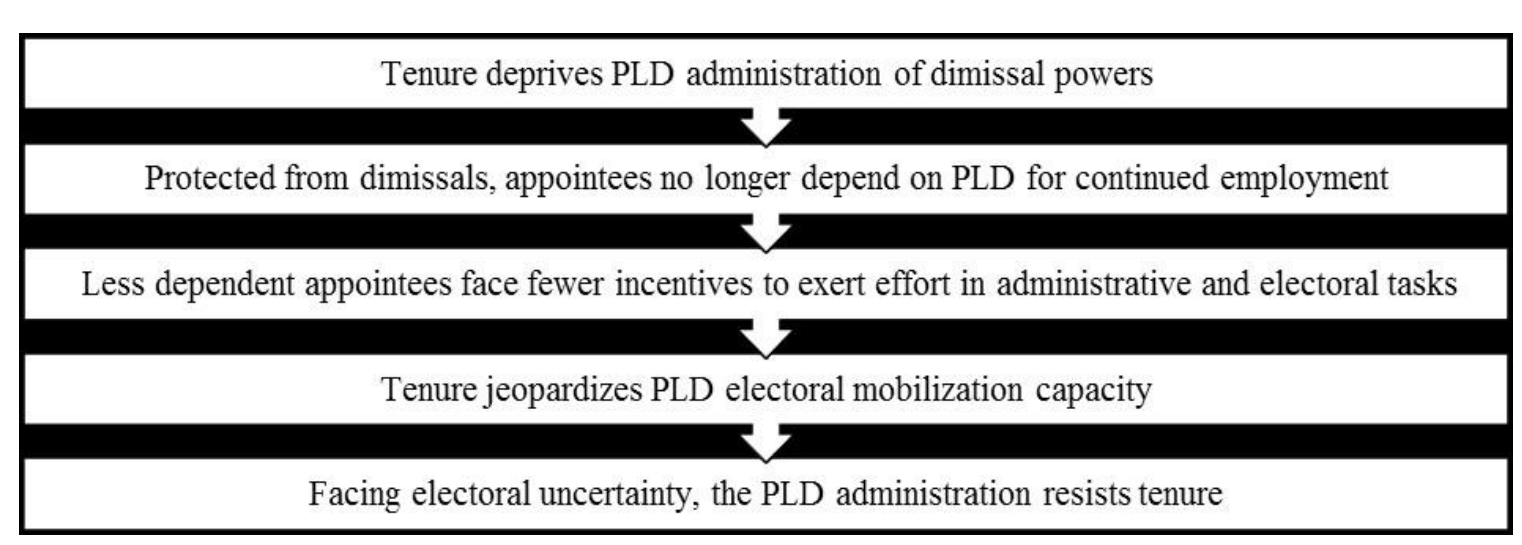

To substantiate these assertions, note that, first, officials feared the loss of dismissal powers associated with tenure: "a minister prefers to retain the right he supposedly has ... to dismiss. And the more career there is, the less he can do it. This disincentivizes the minister." (Interview A) Without dismissal powers, bureaucrats were less dependent on political patrons for employment and material advancement: “[tenured employees] can help [the incumbent] out of gratitude, but the gratitude will be lost. The expectation of clientelist political relations is more durable, because ... you depend on me ... For the minister, the one who is not in the career is better as he will always depend on him.” (Interview M) Governing party officials made this dependency explicit to their 
bureaucratic agents. To illustrate, one PLD official, "when assuming office, ... assembled his personnel to demand loyalty to, solely, the President of the Republic, the party and himself as a condition for permanence in service.” (Scheker Ortiz, 2005, p. 50)

Dependency helped incentivize responsiveness to the needs of the PLD administration: "the only thing that guarantees that you can mobilize the people around you is that these people know that only with you they can obtain a series of benefits. So the leader knows that if these people ... may receive these benefits without him, they don't have as many incentives." (Interview H) These incentives were central to ensure effort in both administrative and electoral campaign tasks.

In regards to administrative work effort, a Director in the Ministry of Agriculture (Interview T), for instance, found that: "the career is security for [the career servants], but a bottleneck as well. Why? Because, in the end, these people will be there, but without performing a task. Physically, they come ... sit in a place and wait for eight hours. After eight hours, they go home. This is not a productive life." Similarly, a Controller General under the PLD administration (Interview E) lamented that, "in my experience, the career servants ... believe that they have a protection from dismissals and don't care about their professional quality." Losses in administrative performance are electorally-consequential in the DR. Bureaucrats channel public services and state goods to governing party supporters; in surveys, party supporters are twice as likely to indicate that they receive such offerings (Espinal, 2013). Reform resistance may in part be explained by this perceived ${ }^{19}$ performance loss of tenured employees. To illustrate, in 2012-2014, tenure incorporations were suspended due to discontent by the Ministry of the Presidency with tenured personnel not fulfilling their responsibilities (Interview G).

\footnotetext{
19 While some authorities perceived a reduction in work effort, tenured employees themselves do not associate tenure with lower work motivation (Oliveros \& Schuster, 2017).
} 
Even more importantly, tenure was feared to reduce effort in electoral campaigns. Threats of dismissals were central to incentivizing campaign support. Ethnographic studies recurrently point to dismissals of employees failing to attend campaign events (Gonzalez-Acosta, 2009). This threat was somewhat less credible for tenured employees - who were, congruently, found to be less willing to participate in electoral campaigns in a survey (Oliveros \& Schuster, 2017). Moreover, tenure was feared to reduce campaign effort by potential recruits: "Imagine a minister with all of his personnel protected with tenure ... 'What do I offer the other [campaign workers outside the state] as an opportunity?' And if those outside know that all those inside here are protected and that the minister cannot fire them, they lost the expectation of being able to obtain a job." (Interview M) In regards to mobilization, tenure was, thus, perceived "as a straightjacket ... When you know that of approximately 8,000 staff, you cannot touch 2,500 [who are tenured] ... you ask: 'what is left?' ... So there are many people who prefer not to incorporate." (Interview U)

The tenure-induced loss of campaign support jeopardized the PLD's incumbency advantage. As a lower bound, 38 percent of public employees admit in surveys to working in electoral campaigns (Espinal, Morgan, \& Seligson, 2012). Bureaucratic campaigning overwhelmingly benefited the incumbent party. With the "state in campaign," most government ministries were incorporated into the governing party campaign command (Participación Ciudadana, 2016, p. 7). This state mobilization provided the PLD with a major incumbency advantage: as aforementioned, the exchange of benefits for political support is central to electoral mobilization in the DR (Kitschelt, 2014).

As a result, the PLD administration feared tenure as a credible constraint and opted against it - and thus resisted a reform which would have greatly benefited its 
own appointees in the bureaucracy. This is not to say the PLD administration was oblivious to the reform benefits and incentives outlined in prior studies and detailed above. Yet, in weighing these longer-run reform benefits against immediate losses of electoral support in a contested election, reform dis-incentives trumped: "Putting into balance the freedom to decide and the freedom to protect ... the freedom to decide weighs more than the freedom to protect my people ... As its principal focus is on mobilization, [the PLD] is less concerned with stabilizing those it appointed." (Interview H) With the governing party fearing a loss of office, the theorized dis-incentives to extend tenure thus trumped longerrun reform benefits. Electoral uncertainty dis-incentivized bureaucratic tenure.

\section{Concluding Remarks}

Is political competition a blessing or curse for institutional reform? Most prior studies identify a positive effect. Incumbents who risk exit from office are argued to seek institutional reforms to insure themselves against potentially hostile successors. Some studies, however, find the opposite effect. In this paper, we argued that inconsistent findings may be expected: political competition may incentivize or dis-incentivize institutional reforms.

Where political competition leads to incumbent turnover - and thus certain exits from office - incumbents may well pursue reform as an insurance mechanism. Examples of reform in such contexts are manifold (e.g. Berliner \& Erlich, 2015; Johnson \& Libecap, 1994). Where it leads to electoral uncertainty for incumbents, however, we argued that the incentive effect is juxtaposed: to resist reform. Reform would deprive incumbents of access to state resources which provide them with electoral advantage. It thus jeopardizes the electoral mobilization capacity of incumbents when they need it most: in contested elections. 
Two distinct potential empirical implications of political competition electoral uncertainty and certain incumbent turnover - thus have contrary effects on institutional reforms. Not least for large-n measurement convenience, studies to-date had frequently confounded the two (see, for instance, Ting et al., 2013, pp. $364 \&$ 379). Our paper suggests that valid insights into the politics of institutional reform require their differentiation. More broadly speaking, it also implies that political competition is a twoedged sword for institutional reforms. Where it leads to incumbent turnover, it may well incentivize reform as theorized in prior studies. Where it induces electoral uncertainty without incumbent turnover, however, it dis-incentivizes reform.

The paper developed and assessed this argument in the context of an overlooked institutional reform: tenure protections in patronage states. Congruent with our general argument about electoral uncertainty and institutional reforms, we posited that electoral uncertainty dis-incentivizes tenure as reform would impair incumbent electoral mobilization capacity: tenure reshapes patron-client relations, reducing the dependency of bureaucratic agents on incumbents for continued employment and material advancement. As a consequence, it deprives incumbents of inducements to incentivize administrative and electoral campaign effort from bureaucratic agents. Thus deriving less electoral advantage from bureaucracy, incumbents resist tenure in particular when elections are contested. Electoral uncertainty dis-incentivizes bureaucratic tenure.

Fine-grained interview and tenure data from the Dominican Republic provided empirical evidence for the argument. Whether these findings travel beyond the DR remains a topic for further empirical inquiry. The absence of large-n panel data on bureaucratic tenure precluded more than suggestive conditional correlations in this paper. There is, however, grounds for optimism. The DR resembles many other patronage states in featuring weak rule of law and a strong executive (Charron, Dahlström, \& Lapuente, 
2012). At the same time, the DR represented a 'most likely' case from the viewpoint of prior studies linking electoral competition with reform: the incumbent could selectively tenure governing party appointees in a context of electoral uncertainty and derive public opinion benefits from reform. Yet, the incumbent resisted reform. This case selection procedure provides some confidence that our findings do travel to other patronage states with electoral competition - albeit not further.

Similarly, the logic of the argument, arguably, extends beyond tenure to any institutional reform which concurrently deprives incumbents and successors of access to electorally advantageous state resources. Next to tenure, anti-corruption, freedom of information, fiscal transparency and oversight reforms - to name a few - share these selfand successor-binding characteristics. Studies of these institutional reforms would thus do well to treat electoral uncertainty and certain incumbent turnover as two distinct explanans - and political competition as a two-edged sword.

At the same time, the paper's findings leave several related empirical puzzles unresolved. Why bureaucratic tenure varies across authoritarian patronage states or whether the effect of political competition on institutional reforms is moderated by other political institutions - such as presidential systems or term limits - is, for instance, not elucidated. A range of avenues for future research on the relationship between political competition and institutional reforms thus remain. 


\section{Cited Interviews}

(current or former positions; all interviews conducted by author in Santo Domingo, DR)

Interview A, Director, National Council for State Reform, April 11, 2013

Interview B, Advisor, MAP, April 24, 2013

Interview C, NGO Analyst, April 17, 2013

Interview D, NGO Analyst, June 14, 2013

Interview E, Controller General, June 6, 2013

Interview F, Academic, June 7, 2013

Interview G, Director, MAP, April 24, 2013

Interview H, Advisor, MAP, April 25, 2013

Interview I, Advisor, Presidency, April 25, 2013

Interview J, Director, Ministry of Education, June 21, 2013

Interview K, Legislator, April 11, 2013

Interview L, NGO Analyst, June 28, 2013

Interview M, Advisor, Ministry of the Economy, April 19, 2013

Interview N, NGO Analyst, April 25, 2013

Interview O, Director, National Office for Administration and Personnel, June 9, 2013

Interview P, Director, MAP, April 24, 2013

Interview Q, NGO Analyst, July 9, 2013

Interview R, Director, Ministry of Health, April 12, 2013

Interview S, Vice-Minister, Ministry of Finance, July 3, 2013

Interview T, Director, Ministry of Agriculture, July 3, 2013 


\section{Bibliography}

Alt, J., Lassen, D. D., \& Rose, S. (2006). The Causes of Fiscal Transparency: Evidence from the U.S. States. IMF Staff Papers, 53, 30-57.

Beck, T., Clarke, G., Groff, A., Keefer, P., \& Walsh, P. (2001). New Tools in Comparative Political Economy: The Database of Political Institutions. The World Bank Economic Review, 15(1), 165-176.

Benito Sanchez, A. B. (2010). La política del poder: Alianzas e interacciones partidistas estratégicas en República Dominicana. Revista de Ciencia Política, 30(3), 751772.

Berliner, D. (2014). The Political Origins of Transparency. The Journal of Politics, 76(02), 479-491.

Berliner, D., \& Erlich, A. (2015). Competing for Transparency: Political Competition and Institutional Reform in Mexican States. American Political Science Review, 109(01), 110-128.

Besley, T., \& Persson, T. (2010). State Capacity, Conflict, and Development. Econometrica, 78(1), 1-34.

Carpenter, D. (2001). The Forging of Bureaucratic Autonomy: Reputations, Networks, and Policy Innovation in Executive Agencies, 1862-1928. Princeton: Princeton University Press.

Charron, N., Dahlström, C., \& Lapuente, V. (2012). No law without a state. Journal of Comparative Economics, 40(2), 176-193. 
Collado, F. (2012). ler Informe Acerca Del Nivel De Cumplimiento De Las Recomendaciones A La Mesa No. 2 De La Iniciativa Participativa Anticorrupción (IPAC). Santo Domingo: Participacion Ciudadana.

Contraloria General de la Republica. (2013). Nomina Gobierno Central y Descentralizado - 2006-2012. Contraloria General de la Republica. Santo Domingo.

Dahlberg, S., Dahlström, C., Sundin, P., \& Teorell, J. (2013). The Quality of Government Expert Survey 2008-2011. Gothenburg: Quality of Government Institute.

Dahlstroem, C., Lapuente, V., \& Teorell, J. (2012). The Merit of Meritocratization: Politics, Bureaucracy, and the Institutional Deterrents of Corruption. Political Research Quarterly, 65(3), 656-668.

Dahlström, C., Lapuente, V., \& Teorell, J. (2012). Public administration around the world. In S. Holmberg \& B. Rothstein (Eds.), Good Government: The Relevance of Political Science (pp. 40-67). Cheltenham: Edward Elgar.

Dahlström, C., Teorell, J., Dahlberg, S., Hartmann, F., \& Lindberg, A. (2015). The QoG Expert Survey Dataset II. Gothenburg: The Quality of Government Institute.

Dunleavy, P., \& Hood, C. (1994). From old public administration to new public management. Public Money \& Management, 14(3), 9-16.

El Día. (2012). César Pina Toribio responde a Hipólito Mejía. Retrieved from http://eldia.com.do/cesar-pina-toribio-responde-a-hipolito-mejia/ 
Espinal, R. (2013). Clientelismo con algunos números. Retrieved from http://hoy.com.do/clientelismo-con-algunos-numeros/

Espinal, R., Morgan, J., \& Hartlyn, J. (2010). Sociedad Civil y Poder Político en República Dominicana. América Latina Hoy, 56, 37-58.

Espinal, R., Morgan, J., \& Seligson, M. (2012). Cultura política de la democracia en República Dominicana y en las Américas. Retrieved from http://www.vanderbilt.edu/lapop/dr/DR_Country_Report_2012_V3_revised_W.p $\underline{\mathrm{df}}$

Finan, F., Olken, B., \& Pande, R. (2015). The Personnel Economics of the State. NBER Working Paper No. 21825.

Folke, O., Hirano, S., \& Snyder, J. (2011). Patronage and Elections in U.S. States. American Political Science Review, 105(03), 567-585.

Frant, H. (1996). High-Powered and Low-Powered Incentives in the Public Sector. Journal of Public Administration Research and Theory, 6(3), 365-381.

Fukuyama, F. (2014). Political Order and Political Decay: From the Industrial Revolution to the Globalization of Democracy. London: Profile Books.

Gailmard, S., \& Patty, J. W. (2007). Slackers and Zealots: Civil Service, Policy Discretion, and Bureaucratic Expertise. American Journal of Political Science, 51(4), 873-889.

Geddes, B. (1991). A Game Theoretic Model of Reform in Latin American Democracies. The American Political Science Review, 85(2), 371-392. 
Geddes, B. (1996). Politician's Dilemma: Building State Capacity in Latin America. Berkeley: University of California Press.

Ginsburg, T. (2003). Judicial Review in New Democracies: Constitutional Courts in Asian Cases. Cambridge: Cambridge University Press.

Gonzalez-Acosta, E. (2009). The Power of Political Parties - Political Participation, Clientelism, and Remittances in the Dominican Republic. (PhD dissertation), New School for Social Research, New York.

Grindle, M. (2012). Jobs for the Boys: Patronage and the State in Comparative Perspective Cambridge: Harvard University Press.

Grzymala-Busse, A. (2003). Political Competition and the Politicization of the State in East Central Europe. Comparative Political Studies, 36(10), 1123-1147.

Grzymała-Busse, A. (2006). The Discreet Charm of Formal Institutions: Postcommunist Party Competition and State Oversight. Comparative Political Studies, 39(3), 271-300.

Hicken, A. (2011). Clientelism. Annual Review of Political Science, Vol. 14, pp. 289$310,2011$.

Horn, M. (1995). The Political Economy of Public Administration: Institutional Choice in the Public Sector. Cambridge: Cambridge University Press.

Iacoviello, M. (2009). Informe de Republica Dominicana. In F. Longo (Ed.), Barómetro De La Profesionalización De Los Servicios Civiles De Centroamérica Y 
República Dominicana (pp. 30-81). Santo Domingo: AECID, FLACSO and SICA.

Ingram, M. (2013). Elections, Ideology, or Opposition? Assessing Competing Explanations of Judicial Spending in the Mexican States. Journal of Law, Economics, and Organization, 29(1), 178-209.

Johnson, R., \& Libecap, G. (1994). The Federal Civil Service System and The Problem of Bureaucracy. Chicago: University of Chicago.

Kitschelt, H. (2014). Democratic Accountability and Linkages Project. 2008-9 Dataset. Retrieved from https://sites.duke.edu/democracylinkage/data/

Kopecky, P., Meyer Sahling, J.-H., Panizza, F., Scherlis, G., Schuster, C., \& Spirova, M. (2016). Party patronage in contemporary democracies: Results from an expert survey in 22 countries from five regions. European Journal of Political Research, $55(2), 416-431$.

LAPOP. (2017). Latin American Public Opinion Project (LAPOP) Database. Retrieved from http://lapop.ccp.ucr.ac.cr/LapopDummies.html

Lapuente, V., \& Nistotskaya, M. (2009). To the Short-Sighted Victor Belong the Spoils: Politics and Merit Adoption in Comparative Perspective. Governance, 22(3), 431-458.

Lohmann, S. (2003). Why Do Institutions Matter? An Audience-Cost Theory of Institutional Commitment. Governance, 16(1), 95-110. 
MAP. (2013a). Concursos 2007, 2008, 2009, 2010, 2011, 2012, 2013 Hasta Junio 10. Ministerio de Administración Pública (MAP). Santo Domingo.

MAP. (2013b). Servidores Públicos Incorporados a Carrera Administrativa por Actos y Concursos. Ministerio de Administración Pública. Santo Domingo.

Marsteintredet, L. (2010). The Dominican Republic and the Fall of Balaguer 1994-1996: Presidential Breakdown or Democratic Transition? In M. Llanos \& L. Marsteintredet (Eds.), Presidential Breakdowns in Latin America: Causes and Outcomes of Executive Instability in Developing Democracies (pp. 181-196). New York: Palgrave Macmillan.

Meilán, X. (2014). Dominican Republic's 2012 presidential election. Electoral Studies, $33,347-350$.

Meyer-Sahling, J.-H. (2006). The rise of the partisan state? Parties, patronage and the ministerial bureaucracy in Hungary. Journal of Communist Studies and Transition Politics, 22(3), 274-297.

Miller, G. (2000). Above Politics: Credible Commitment and Efficiency in the Design of Public Agencies. Journal of Public Administration Research and Theory, 10(2), 289-328.

Moe, T. M. (1989). The Politics of Bureaucratic Structure. In J. E. Chubb \& P. E. Peterson (Eds.), Can the Government Govern? Washington, DC: The Brookings Institution. 
Nistotskaya, M., \& Cingolani, L. (2016). Bureaucratic Structure, Regulatory Quality, and Entrepreneurship in a Comparative Perspective: Cross-Sectional and Panel Data Evidence. Journal of Public Administration Research and Theory, 26(3), 519534.

O'Dwyer, C. (2006). Runaway State-Building: Patronage Politics and Democratic Development. Baltimore: Johns Hopkins University Press.

Oliveros, V. (2013). A Working Machine: Patronage Jobs and Political Services in Argentina. (Ph.D.), Columbia University, New York.

Oliveros, V. (2016). Making it Personal: Clientelism, Favors, and the Personalization of Public Administration in Argentina. Comparative Politics, 48(3), 373-391.

Oliveros, V., \& Schuster, C. (2017). Merit, Tenure, and Bureaucratic Behavior: Evidence From a Conjoint Experiment in the Dominican Republic. Comparative Political Studies, Online First.

Participación Ciudadana. (2007). Segundo Informe Alternativo de Organizaciones de la Sociedad Civil Sobre la Aplicacion de la Convencion Interamericana contra la Corrupcion Por Parte del Estado Dominicano. Retrieved from Santo Domingo:

Participación Ciudadana. (2016). Quinto Informe de Observación Electoral. Retrieved from https://issuu.com/pciudadana/docs/5to_informe-de-observaci_n-elector

Rauch, J., \& Evans, P. (2000). Bureaucratic structure and bureaucratic performance in less developed countries. Journal of Public Economics, 75(1), 49-71. 
Robinson, J., \& Verdier, T. (2013). The Political Economy of Clientelism. The Scandinavian Journal of Economics, 115(2), 260-291.

Rose-Ackerman, S., Desierto, D. A., \& Volosin, N. (2011). Hyper-Presidentialism: Separation of Powers without Checks and Balances in Argentina and Philippines. Berkeley Journal of International Law, 246.

Ruhil, A., \& Camões, P. (2003). What Lies Beneath: The Political Roots of State Merit Systems. Journal of Public Administration Research and Theory, 13(1), 27-42.

Scheker Ortiz, L. (2005). La Ley de Servicio Civil. Reforma y Aplicación. In ONAP \& Participación Ciudadana (Eds.), Mesas de Búsqueda de Consenso para la Implementación de la Ley de Servicio Civil y Carrera Administrativa (pp. 45-52). Santo Domingo: ONAP.

Schuster, C. (2014). Strategies to Professionalize the Civil Service - Lessons from the Dominican Republic. Washington DC: Inter-American Development Bank.

Schuster, C. (2015). When the Victor Cannot Claim the Spoils: Institutional Incentives for Professionalizing Patronage States. (PhD), The London School of Economics and Political Science (LSE), London.

Schuster, C. (2017). Legal reform need not come first: Merit-based civil service management in law and practice. Public Administration, Early View.

Shepsle, K. (1972). The Strategy of Ambiguity: Uncertainty and Electoral Competition. American Political Science Review, 66(2), 555-568. 
Silberman, B. (1993). Cages of Reason: The Rise of the Rational State in France, Japan, the United States, and Great Britain. Chicago: University of Chicago Press.

Ting, M., Snyder, J., Hirano, S., \& Folke, O. (2013). Elections and reform: The adoption of civil service systems in the U.S. states. Journal of Theoretical Politics, 25(3), 363-387.

World Bank. (2008). Public Sector Reform: What Works and Why? - An IEG Evaluation of World Bank Support. Washington DC: World Bank.

World Bank. (2013). Worldwide Governance Indicators. Retrieved from Washington DC:

World Bank. (2014). Rentas o reformas? La economía política del desarrollo en República Dominicana Retrieved from Washington DC: 